\title{
Molecular and biochemical characterization of oxidative stress in tomato plants cultivated with lead $(\mathrm{Pb})$
}

\begin{abstract}
Heavy metals are dangerous pollutants of water and soil coming, in first place, from anthropogenic activity. Lead $(\mathrm{Pb})$ can be accumulated in soil surface and it is easily take by plants inducing many symptoms of toxicity. Several research suggests that $\mathrm{Pb}$ toxicity leads to the induction of key enzymes of antioxidant defense system in tomato plants. This mini review will show the influence of $\mathrm{Pb}$ in some enzymes of tomato oxidative system focusing in the analysis of protein content and the enzymes glutathione reductase and superoxide dismutase in different parts of the plant (leaves and stem), some genes related to the oxidative stress of tomato were also study.
\end{abstract}

Keywords: Glutathione reductase, heavy metals, isoenzymes, lead, molecular mechanism, Solanum lycopersicum, superoxide dismutase
Volume 2 Issue 6 - 2018

\author{
Eduardo Fidel Héctor Ardisana,' Alianna \\ Machín Suárez, ${ }^{2}$ Sandra Pérez Álvarez ${ }^{3}$ \\ 'Higher Polytechnic School of Chimborazo, Riobamba, Ecuador \\ ${ }^{2}$ Agrarian University of Havana, Cuba \\ ${ }^{3}$ National Polytechnic Institute, Mexico
}

\begin{abstract}
Correspondence: Sandra Pérez Álvarez, National Polytechni Institute, CIIDIR-IPN, Sinaloa Unit, Department of Agricultural Biotechnology, Blvd. Juan de Dios Bátiz Paredes 250, Guasave, Sinaloa, CP 8I I0I, Tel 0052687 I 269840,

Email perezalvarezsandra20I5@gmail.com
\end{abstract}

Received: August 14, 2018 | Published: December 19, 2018

\section{Introduction}

The accumulation of heavy metals in soils is mainly due to anthropogenic activity. Heavy metals are directly related to the risks of soil contamination, plant toxicity and the negative effects on the quality of natural resources and the environment, dangers dependent on various aspects such as the specific toxicity of the metal, bioaccumulation, persistence and non-biodegradability. ${ }^{1}$ In soil, the greatest danger lies in its accumulation by plants and transfer to animals, including humans, ${ }^{2}$ also these metals are not biodegradables. An example of heavy metals are: aluminum (Al), barium $(\mathrm{Ba})$, beryllium $(\mathrm{Be})$, cobalt $(\mathrm{Co})$, copper $(\mathrm{Cu})$, tin $(\mathrm{Sn})$, iron $(\mathrm{Fe})$, manganese $(\mathrm{Mn})$, cadmium $(\mathrm{Cd})$, mercury $(\mathrm{Hg})$, lead $(\mathrm{Pb})$, arsenic (As), chromium (Cr), molybdenum (Mo), nickel (Ni), silver $(\mathrm{Ag})$, selenium $(\mathrm{Se})$, thallium $(\mathrm{Tl})$, vanadium $(\mathrm{Va})$, gold $(\mathrm{Au})$ and zinc $(\mathrm{Zn}){ }^{3}$

The absorption of $\mathrm{Pb}$ is a serious public health risk; causes retardation of mental and intellectual development of children, causes hypertension and diseases Cardiovascular in adults. Intoxication is due to the accidental ingestion of lead compounds or the ingestion by animals of forages or foods with lead, from environmentally contaminated areas. ${ }^{4}$ Heavy metals can be readily taken up by vegetable roots, and can be accumulated at high levels in the edible parts, ${ }^{5,6}$ tomato is one of these vegetables. For this reason is relevant to develop this study in leaves and stem of tomato plants where some enzymes and genes related to oxidative stress were study.

\section{Molecular characterization of S. lycopersicum cv. micro-tom}

Growth reduction was observed in tomato plants of cv Micro-Tom under $\mathrm{Pb}$-stress (Figure 1). Chlorosis and necrotic lesions appeared after 35 days of growth, indicating altered mineral nutrient absorption and photosynthesis. ${ }^{7}$ Tomato plants under $\mathrm{Pb}$-stress for 35 days at the highest concentration of $10 \mathrm{mg} \mathrm{kg}^{-1}$ showed lost almost all the leaves, with reduction in growth length. ${ }^{7}$ Superoxide dismutase
(SOD), Translationally Controlled Tumour Protein (TCTP) and Isoflavone Reductase (IFR)genes were studied to know their behavior at molecular and biochemical level in tomato plants cv. Micro-Tom under $\mathrm{Pb}$ stress. The three genes (SOD, TCTP and IFR) showed different expression profiles under the tested concentrations and depending on the collection phase (Figure 2). Ubiquitin was used as control gene due to its basal stable expression, as commonly used in different crops, with the ubiquitin-conjugating enzyme and elongation factor-1 regarded as the most stable based on their transcriptional profiles in Oryza sativa L. and Pennisetum ciliare. ${ }^{8,9}$
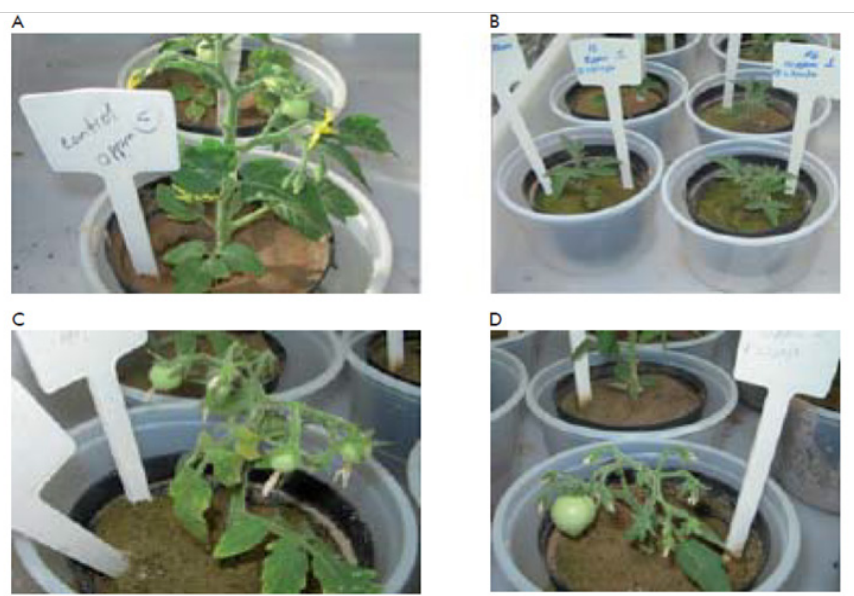

Figure I Plant growth at different lead soil content conditions. (A) Control without lead ( $\mathrm{PbAc2}$ ), respectively. (B) Growth at 5 and $10 \mathrm{mg} / \mathrm{kg}$, left and right, respectively, ten days after transplantation. (C \& D) Growth at 5 and $10 \mathrm{mg} / \mathrm{kg}$ of lead, 35 days after transplantation.

SOD expression was lower in the first phase for both $\mathrm{Pb}$ treatments and higher in the second phase, specifically at $5 \mathrm{mg} \mathrm{kg}^{-1}$ of $\mathrm{PbAc}_{2}$. A possible explanation for second phase, as for other induced enzymes, may be caused by the possible temporal expression of SOD, this is the increased production of superoxide radicals due to the rise in ROS 
production by $\mathrm{Pb}$ toxicity. The higher expression of SOD at $5 \mathrm{mg} \mathrm{kg}^{-1}$ of $\mathrm{PbAc}_{2}$ in the mainly transitional. However, this response also may be a consequence of SOD-related transcriptional activity genes. So, in this study, SOD expression was higher at the lower heavy metal concentration.
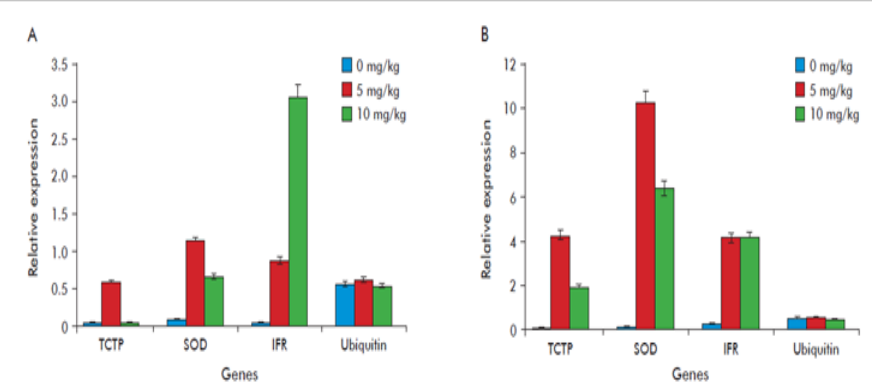

Figure 2 Relative expression of the transcriptionally-controlled tumor protein (TCTP), superoxide dismutase (SOD) and isoflavone reductase (IFR) in tomato plants grown on different lead $\left(\mathrm{PbAc}_{2}\right)$ concentrations $(0,5$ or 10 $\mathrm{mg} \mathrm{kg^{-1 }}$ ). (A) Phase germination-flowering. (B) Phase flowering-fructification. Ubiquitin was used as lead unrelated protein expression control.

A lower expression at $10 \mathrm{mg} \mathrm{kg}^{-1}$ of $\mathrm{PbAc}_{2}$ may suggest that higher concentrations could damage plants, which is suggested by the fact that the growth of plants at this concentration was affected. The expression of SOD at both $\mathrm{Pb}$ concentrations used in this research indicates that it may be involved in the antioxidative process under $\mathrm{Pb}$ induced stresses, since SOD is considered to be a crucial component in biological defense against oxidative stress. ${ }^{10}$

\section{Biochemical characterization of S. lycopersicum cv. Micro-Tom}

The biochemical analysis showed differences between SOD $\mu$ mol $\mathrm{min}^{-1}$ per milligram of protein $\left.\mathrm{FW}\right), \mathrm{GR}\left(\mu \mathrm{mol} \mathrm{min}{ }^{-1}\right.$ per milligram of protein FW) and total proteins (Figure 3). During the experimental period, the content of SOD was higher at $10 \mathrm{mg} \mathrm{kg}^{-1}$ of $\mathrm{PbAc}_{2}$ with significant differences with respect to the control and $5 \mathrm{mg} \mathrm{kg}^{-1}$ of $\mathrm{PbAc}_{2}$. This is also corroborated by the fact that plant growth at this concentration was really affected. Plants exposed to $\mathrm{Pb}$ stress also show rapid and temporary drops in growth rate and activate antioxidant defense system by producing ROS, which alters gene expression and enzyme activity patterns of SOD. GR content was higher also at 10 $\mathrm{mg} \mathrm{kg}{ }^{-1}$ of $\mathrm{PbAc}_{2}$, with significant differences with respect to the other two treatments. This enzyme is part of the defenses system against oxidative stress. GRs are indispensable components of ascorbateglutathione pathway, required to scavenge $\mathrm{H}_{2} \mathrm{O}_{2}$ produced mainly in chloroplasts and other cell organelles and to maintain the redox state of the cell. ${ }^{11}$

This results show increased GR activity in $\mathrm{Pb}$ treated tomato plants, which suggests possible involvement of GR in regenerating GSH under $\mathrm{Pb}$ toxicity conditions to increase GSH/GSSG ratio and the total glutathione pool. Total proteins were higher in the absence of $\mathrm{PbAc}_{2}$ (control), which means there could be degraded with the other two concentrations used. Production of ROS takes place in cell under normal conditions, however adverse environmental conditions that interrupt cellular homeostasis could produce oxidative damage to proteins, DNA and to the lipids. ${ }^{12}$ This could explain why total proteins decreased at higher concentrations of $\mathrm{Pb}$.
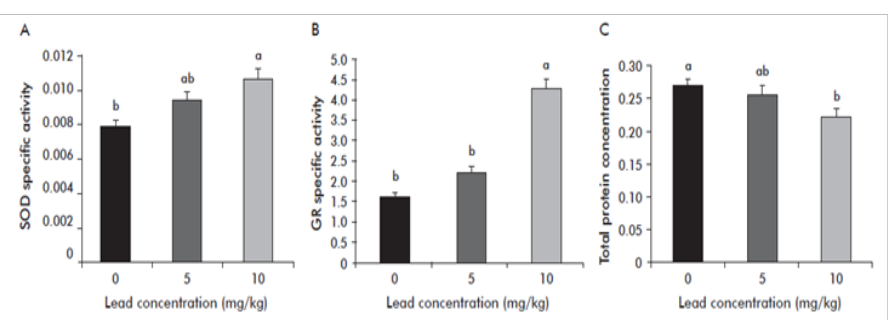

Figure 3 Effect of lead $\left(\mathrm{PbAc}_{2}\right)$ concentrations on protein expression in tomato plants. (A) Superoxide dismutase (SOD) $\left(\mu \mathrm{mol} \mathrm{min}^{-1}\right.$ per milligram of protein). (B) Glutathione reductase (GR) ( $\mu \mathrm{mol} \mathrm{min}^{-1}$ per milligram of protein). (C) Total proteins of tomato plants.

\section{Molecular characterization of S. lycopersicum cv. Amalia}

The seeds of tomato plants cv. Amalia were planted in trays containing a 1:1 (v/v) mixture of vermiculite supplemented with NPK (nitrogen, phosphorus and potassium) 10:10:10(g) and a commercial product (Plantmax HT Eucatex, Sao Paulo, Brazil ) at 2\% weight: volume. The sowing was carried out in the period between September 2010 and December 2011 in a greenhouse located at the University of Sao Paulo/Higher School of Agriculture, Brazil. After the first pair of true leaves appeared, the seedlings were transplanted into $1 \mathrm{~L}$ Leonard containers (experimental unit) containing sand and three treatments were established with different concentration of $\mathrm{Pb}(0,50$ and $100 \mathrm{mg}$ $\mathrm{kg}^{-1}$ ) and two part of the tomato plant cv. Amalia (leaves and stem). ${ }^{13}$

\section{Biochemical characterization of S. lycopersicum cv. Amalia}

In the treatments analyzed, no significant differences were found in the leaves in terms of total protein content, but in the stem the highest concentration $\left(100 \mathrm{mg} \mathrm{kg}^{-1}\right)$ was significantly higher than the control in $135.1 \%$ and that the treatment with $50 \mathrm{mg} \mathrm{kg}^{-1}$ of $\mathrm{PbAc}_{2}(136.59 \%)$, causing a significant decrease in the variable analyzed in both treatments $\left(0\right.$ and $50 \mathrm{mg} \mathrm{kg}^{-1} \mathrm{of} \mathrm{PbAc}_{2}$ ) (Figure 4A \& 4B). This increase in the content of total soluble proteins in the maximum concentration of $\mathrm{PbAc}_{2}$ used could be due to a saturation in the mechanisms of retention of $\mathrm{Pb}$ in the stem, and consequently the finite capacity of this organ to act as a reservoir of the metal, ${ }^{14}$ which continues to the leaves, where, although without significant differences, the protein content decreased at the maximum concentration tested. The activity of the GR in the presence of different concentrations of $\mathrm{PbAc}_{2}$ shows an increase in both parts of the analyzed plant being significant in the leaves (Figure 5A \& 5B).

The activity of the GR in the leaves showed significant differences for the three treatments, with an increase when using $50 \mathrm{mg} \mathrm{kg}^{-1}$ of $\mathrm{PbAc}_{2}$ of $157.8 \%$ compared to the control, that is, with this concentration the activity of the enzyme responds to stress by $\mathrm{Pb}$, possibly due to a requirement for glutathione in the reduced form as a substrate for incorporation into phytochelatins or the ascorbateglutathione cycle to remove $\mathrm{H}_{2} \mathrm{O}_{2},{ }^{15}$ however it is necessary to conduct future research on the synthesis of phytochelatins and other antioxidant systems including metabolites such as glutathione, ascorbate and amino acids which could be altered in responses to $\mathrm{Pb} .{ }^{16}$

The activity of the SOD was significantly different in the leaves in all the treatments tested (Figure $5 \mathrm{C}$ ) with the activity being higher 
at $50 \mathrm{mg} \mathrm{kg}^{-1}$ of $\mathrm{PbAc}_{2}$ in $342.47 \%$ compared to the control, followed by the treatment of $100 \mathrm{mg} \mathrm{kg}^{-1}$ which increased in a $227.40 \%$. In tomato cv. Micro Tom Pérez et al..$^{7}$ obtained the highest activity of the enzyme with $10 \mathrm{mg} \mathrm{kg}^{-1}$, the maximum concentration used taking into account that this cultivar in less than two months is fructifying, this demonstrates once again the detoxifying role of SOD. In the stems, significant differences were found between the maximum concentration of $\mathrm{PbAc}_{2}\left(100 \mathrm{mg} \mathrm{kg}^{-1}\right)$ and the other treatments (Figure $5 \mathrm{D})$. The lowest values of the enzyme were found $(43.43 \%$ less than the control) in said treatment $\left(100 \mathrm{mg} \mathrm{kg}^{-1}\right)$. ); while with the lowest concentration of $\mathrm{Pb}$ there were no differences with the control.
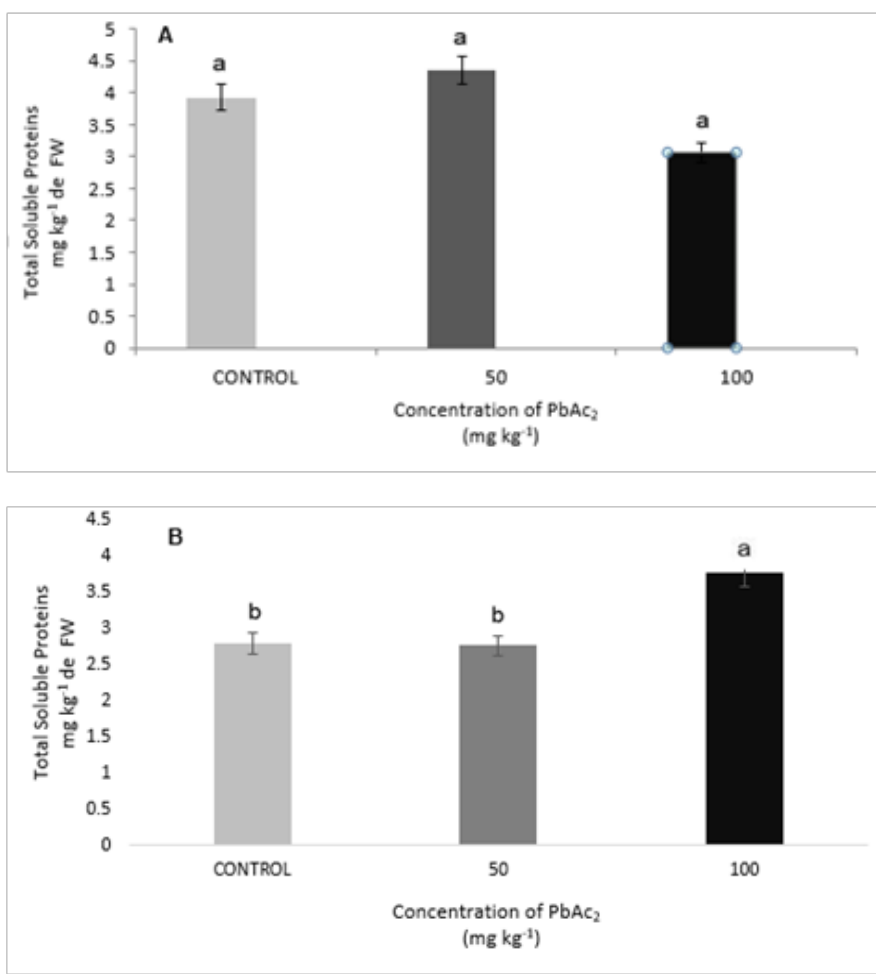

Figure 4 Total soluble proteins ( $m g g^{-1}$ of FW); (A) Leaves protein. (B) Stems protein of S. lycopersicum cv. Amalia Different letters indicate significant differences $(p \leq 0.05)$.
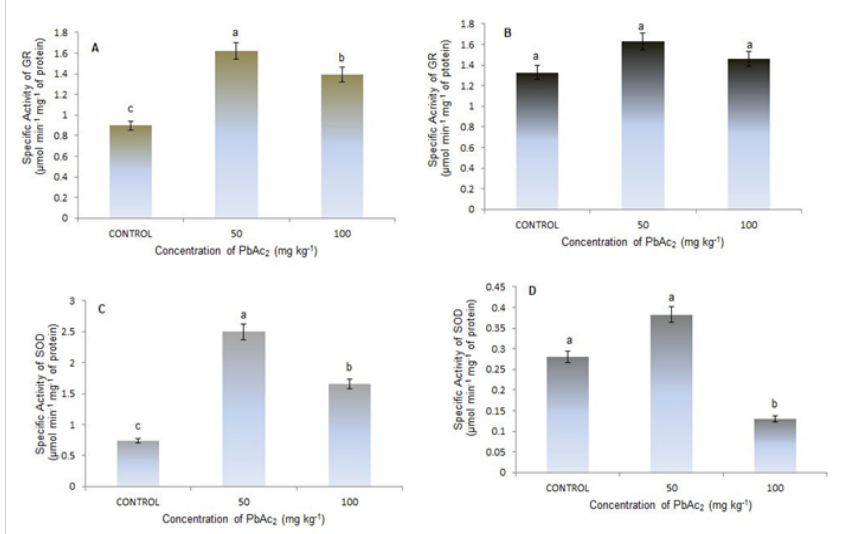

Figure 5 Enzyme activity ( $\mu \mathrm{mol} / \mathrm{min} / \mathrm{mg}$ protein); (A) GR leaves. (B) GR stems. (C) SOD leaves. (D) SOD stems of S. lycopersicum cv. Amalia Different letters indicate significant differences $(p \leq 0.05)$.

\section{Conclusion}

In the leaves the behavior of both enzymes was similar increasing in the concentration of $50 \mathrm{mg} \mathrm{kg}^{-1}$ and decreasing in the maximum concentration used of the metal demonstrated that this concentration of tomato is toxic because it inhibits or reduces the activity of both enzymes. In the stem there were no significant differences in the activity of the GR but in the activity of the SOD significant differences were found being much lower at the maximum concentration tested, this behavior is due to both enzymes have different functions to combat oxidative stress, SOD is identified as an enzymatic protector against the peroxidation reactions that occur in the plant ${ }^{17}$ and GR is an indispensable component of the enzymatic ascorbate-glutathione pathway to eliminate $\mathrm{H}_{2} \mathrm{O}_{2}$ that is produced mainly in chloroplasts to maintain the redox state of the cell, ${ }^{18}$ indicating that the majority function of the GR is in the leaves.

\section{Acknowledgments}

We are very grateful to TWAS (Academy of Sciences for developing countries) and $\mathrm{CNPq}$ for providing the opportunity to carry out this research at the University of São Paulo / School of Agriculture "Luiz de Queiros" in Brazil.

\section{Conflicts of interest}

Author declares that there is no conflicts of interest.

\section{References}

1. Wang S, Wang Y, Zhang R, et al. Historical levels of heavy metals reconstructed from sedimentary record in the Hejiang River, located in a typical mining region of Southern China. Sci Total Environ. 2015;532:645-654.

2. Liu X, Song Q, Tang Y, et al. Human health risk assessment of heavy metals in soil-vegetable system: A multi-medium analysis. Sci Total Environ. 2013;463-464:530-540.

3. Concon JM. Heavy metals in food. Food Toxicology, Part B: Contaminents and Additives. 2009;3(4):1043-1045.

4. Agency for toxic substances and disease control. División de Toxicología y Medicina Ambiental. Departamento de Salud y Servicios humanos de los EEUU. Washington (USA): Servicio de Salud Pública; 2011. 269 p.

5. Yang Y, Zhang FS, Li HF, et al. Accumulation of cadmium in the edible parts of six vegetable species grown in Cd-contaminated soils. $J$ Environ Manag. 2009;90:1117-1122.

6. Jolly YN, Islam A, Akbar S. Transfer of metals from soil to vegetables and possible health risk assessment. Springer Plus. 2013;2:385-391.

7. Pérez S, Ahmed AIS, Cabezas D. Molecular and biochemical characterization of tomato (Solanum lycopersicum L.) plants cv. Micro-Tom under lead $(\mathrm{Pb})$-induced stress. Biotecnología Aplicada. 2013;30:194-198.

8. Jain M, Nijhawan A, Tyagi AK, et al. Validation of housekeeping genes as internal control for studying gene expression in rice by quantitative realtime PCR. Biochem Biophys Res Commun. 2006;345(2):646-651.

9. Singh M, Burson B, Finlayson S. Isolation of candidate genes for apomictic development in buffelgrass (Pennisetum ciliare). Plant Mol Biol. 2007;64(6):673-682.

10. Abu-Romman S, Shatnawi M. Isolation and expression analysis of chloroplastic copper/ zinc superoxide dismutase gene in barley. Afr J Bot. 2010;77(2):328-34. 
11. Malecka A, Jarmuszkiewicz W, Tomaszewska B. Antioxidative defense to lead stress in subcellular compartments of pea root cells. Acta Biochim Polon. 2001;48(3):687-698.

12. Pitzschke A, Fornazi C, Hirt H. Reactive oxygen species signalling in plants. Antioxid Redox Signal. 2006;8(9-10):1757-1764.

13. Machín-Suárez A, Sánchez-Chávez E, Héctor EFA, et al. Actividad de enzimas del estrés oxidativo en plantas de tomate var. Amalia en respuesta al plomo. Hortic Bras. 2017;35(2):216-223.

14. Abreu CB, Sacramento BL, Teixeira AA, et al. Nutritional and biochemical changes induced by lead in sunflower (Helianthus annuus L.). Ciências Agrárias. 2016;37:1229-1242.
15. Gomes-Junior RA, Moldes C, Delite F, et al. Antioxidant metabolism of coffee cell suspension cultures in response to cadmium. Chemosphere. 2006;65:1330-1337.

16. Sharma P, Dubey RS. Lead toxicity in plants. Braz J Plant Physiol. 2005; 17:35-52.

17. Monk LS, Fagerstedt KV, Crawford RMM. Oxygen toxicity and superoxide dismutase as an antioxidant in physiological stress. Physiol Plantarum. 1989;76:456-459.

18. Asada K. Ascorbate peroxidase-a hydrogen peroxide scavenging enzyme in plants. Plant Physiol. 1992;85:235-241 